Revista Brasil. Bot., V.31, n.3, p.529-536, jul.-set. 2008

\title{
Ontogenesis of stomata in Velloziaceae: paracytic versus tetracytic?
}

\author{
MARINA MILANELLO DO AMARAL ${ }^{1}$ and RENATO DE MELLO-SILVA ${ }^{1,2}$
}

(received: August 02, 2007; accepted: July 10, 2008)

\begin{abstract}
Ontogenesis of stomata in Velloziaceae: paracytic versus tetracytic?). In Velloziaceae, the number of subsidiary cells has been used to characterize species and support groups. Nevertheless, the homology of the stomatal types have not been scrutinized. Stomatal ontogenesis of Vellozia epidendroides and V. plicata, assigned to have tetracytic stomata, and of V. glauca and Barbacenia riparia, assigned to have paracytic stomata, were investigated. In the four species studied, stomata followed perigenic development. Subsidiary cells arise from oblique divisions of neighbouring cells of the guard mother cell (GMC). These cells are elongated and parallel to the longer axis of the stoma. Polar cells show wide variation, following the shape and size of the epidermal cells in the vicinity. Hence, these cells cannot be called subsidiary cells. This wide variation is due to a much higher density of stomata in some regions of the leaf blade. This distribution of stomata forces the development of short polar cells, leading to an apparently tetracytic stomata. In regions of low concentration of stomata, higher spatial availability between the GMCs allows the elongation of polar cells, leading to evident paracytic stomata. Therefore, the four studied species are considered braquiparacytic, questioning the classification of stomata into tetracytic and paracytic in Velloziaceae.
\end{abstract}

Key words - ontogenesis, paracytic, stomata, tetracytic, Velloziaceae

RESUMO - (A ontogênese dos estômatos em Velloziaceae: paracítico versus tetracítico?). Em Velloziaceae, o número de células subsidiárias tem sido utilizado para caracterizar espécies e sustentar grupos. Entretanto, a homologia dos tipos de estômatos nunca foi escrutinizada. Para isso, a ontogênese dos estômatos de Barbacenia riparia e Vellozia glauca, representando estômatos paracíticos, e $V$. epidendroides e V. plicata, representando estômatos tetracíticos, foi investigada. Nas quatro espécies, foi evidenciada ontogênese perígina. As células subsidiárias se originam a partir de divisões oblíquas das células vizinhas da célula-mãe de células-guarda (GMC), que são alongadas paralelamente em relação ao maior eixo do estômato. Células polares apresentam grande diversificação, acompanhando o padrão de tamanho e formato das outras células epidérmicas, e assim não podem ser denominadas células subsidiárias. Essa ampla variação se deve a uma maior densidade de estômatos em algumas regiões da superfície foliar, forçando o desenvolvimento de células polares curtas e conduzindo a estômatos aparentemente tetracíticos. Em regiões de baixa concentração de estômatos, a maior disponibilidade espacial entre GMCs permite o alongamento de células polares, conduzindo a estômatos evidentemente paracíticos. Os estômatos das quatro espécies são então classificados como braquiparacíticos. A classificação de estômatos em tetracítico e paracítico em Velloziaceae deve ser questionada.

Palavras-chave - estômatos, ontogênese, paracítico, tetracítico, Velloziaceae

\section{Introduction}

The stomatal apparatus, or stoma, is formed by two guard cells that delimit a pore, and are often surrounded by subsidiary cells. Guard cells are specialized structures, different from the other epidermal cells (Tomlinson 1974, Esau 1977, Rasmussen 1981, Baranova 1987). The number and arrangement of subsidiary cells has long been used as characters in systematics (Stebbins \& Khush 1961, Esau 1977, Baranova 1987). In Velloziaceae, the number of subsidiary cells have been used to characterize species and support groups (Ayensu 1969, 1974, Dahlgren et al. 1985, Menezes et al. 1994, Mello-Silva 2000, 2005). In these studies, two types of stomata have been assigned

\footnotetext{
1. Universidade de São Paulo, Instituto de Biociências, Caixa Postal 11461, 05422-970 São Paulo, SP, Brazil.

2. Author for correspondence: mellosil@usp.br
}

to Velloziaceae: (1) stomata with two subsidiary cells corresponding to one of the paracytic types of Metcalfe (1961) or brachyparacytic type of Dilcher (1974), and (2) stomata with four subsidiary cells, the tetracytic type of Metcalfe (1961). These two character states have been used by Menezes et al. (1994) and Mello-Silva (2000, 2005). These studies have shown that this character supports two large groups in Velloziaceae and in Vellozia.

Despite the taxonomic importance of this character, morphologically identical stomata can have distinct origins. On the other hand, similar ontogenetic patterns can form different types of stomata (Tomlinson 1974, Baranova 1987). The correct determination of homologies is essential in cladistic studies, both molecular and nonmolecular. A detailed study of stomatal ontogeny in Velloziaceae can help to classify stomata in this group in a much more precise manner. Moreover, tetracytic stomata have been shown to be homoplastic in three 
distant terminals (Mello-Silva 2000). These results suggest possible problems in homology assessment.

This study investigates the influence of size, shape and arrangement of epidermal cells on the final configuration of stomata and tries to explain stomatal development in Velloziaceae based in two hypotheses: (1) the two types of stomata develop due to differences in cell divisions during the ontogeny, regardless of space availability; (2) space availability interferes on the shape of subsidiary cells.

\section{Material and methods}

Leaves of two species of Velloziaceae with tetracytic stomata, Vellozia epidendroides Mart. ex Schult. \& Schult.f. (Amaral 3) and V. plicata Mart. (Menezes 448), were collected at the garden of the Institute of Biosciences of the University of São Paulo (Brazil). In addition, leaves of two species with paracytic stomata, Barbacenia riparia (N. L. Menezes \& Mello-Silva) Mello-Silva (Menezes 1167) and V. glauca Pohl (Sasaki 665) were collected at the garden of the Institute of Biosciences of the University of São Paulo (Brazil), and in Pedregulho (Brazil), respectively. Vouchers of all materials are deposited in the herbarium SPF. Each species was represented by three specimens. Leaves were fixed in FAA (Johansen 1940) for approximately $24 \mathrm{~h}$. Epidermal peels were taken using the method of Franklin (1945) - with leaves being macerated for only one hour in order to minimize damage on the epidermal cells. The proximal and median thirds of leaves are the areas with developing stomata. All peels were stained with safranin and mounted in glycerine. Free-hand transversal sections of leaves were cleared with sodium hypochlorite and stained with safrablau (Bukatsch 1972), modified by Kraus \& Arduin (1997). Images were made with a photomicroscope Leica DMLB.

In addition to the new materials analyzed here, results from Mello-Silva $(2000,2005)$ were also taken into account for comparisson, namely leaves of Vellozia epidendroides (Menezes 216), V. glauca (Mello-Silva CFCR11585) and V. plicata (Coradin 6296, Mello-Silva 427). In this case, peels were taken and prepared using the method of Ram \& Nayyar (1974).

The terminology of Pant (1965) was followed in classifying the stomatal ontogeny as mesogenous, when guard cells and subsidiary cells arise from the same guard mother cell (GMC); periginous, when guard cells arise from the GMC, whereas subsidiary cells arise from ground epidermal cells; and mesoperiginous, when guard cells and at least one subsidiary cell arise from the GMC.

\section{Results}

The stomatal ontogenesis of the four species is remarkably similar and are here described together (figures 1-7). The protodermal cells in the proximal, immature area of the leaf are quite similar, except for smaller rectangular cells organized in rows, which were considered guard mother cells (GMCs -0 , figures 1-3, 5). Following the same row of one of those GMCs to mature areas of the leaf, two guard cells $\left(0^{1}\right)$ can be found (figures 2, 4, 5-7). Four cells surround the GMCs: Two of them are elongated parallel to the longer axis of the stoma and are called cells type 1; the other two are elongated parallel to the shorter axis of the stoma and are called cells type 2 or polar cells (figure 1 ) - as proposed by Tomlinson (1974) and Dahlgren \& Clifford (1982).

In the median region of the leaf, three types of arrangement of cells type 1 are found around the guard cells and can be identified as stomatal developmental steps. Guard cells can be accompanied, in each side, by i) two cells type $1^{1}$, which represent type 1 daughter cells, sharing an oblique anticlinal wall (figures 1,2,6); ii) a trapezoid cell type $1^{2}$, sharing two oblique anticlinal walls with its mother-cell, $1^{1}$, and its sister cell, $1^{2}$ (figures $3,5)$; or iii) two cells type $1^{3}$, which are $1^{2}$ trapezoid cell daughters (figures 4, 6-7). Only the cells type $1^{3}$ adjacent to the guard cells become the subsidiary cells (figures 4 , 6-7). Cells type 2, on the other hand, can give rise to two $2^{1}$ daughter cells (figure 3 ). These divisions can be oblique or, rarely, non-oblique, and the cells produced are not modified into subsidiary cells. The shape, size and arrangement of these cells follow the other epidermal cells, representing a wide range of variation of cells type 2 and their derivatives $2^{1}$ (figures 8-19). If ground epidermal cells are short, so are the cells type 2 or $2^{1}$, and the stomatal apparatus resembles a tetracytic stomata. On the other hand, if ground epidermal cells and the cells type 2 or $2^{1}$ are long, the stomatal apparatus resembles a paracytic stoma. Barbacenia riparia (figure 8) and Vellozia plicata (figure 11) lack leaf-furrows, and show both situations randomly distributed over the leaf (figures 9-10, 12-13). Vellozia epidendroides (figure 14) and V. glauca (figure 17) have leaf-furrows, and show stomata with short cells type 2 generally present in the furrows and stomata with long cells type 2 generally present outside the furrows (figures 15-16, 18-19). Since the cells type 2 cannot be distinguished from the other epidermal cells, stomata from both of these species cannot be tetracytic.

Another configuration of mature stomata can also be present in V. plicata. Stomata inserted between needlelike epidermal cells present cells type $1^{2}$ instead of cells type $1^{3}$. Thus, more than four cells can surround the guard cells (figure 13). Since derivatives of cells type 1 and 2 can push each other in tight spaces, some of them are difficult to classify into type 1 or type 2 . 

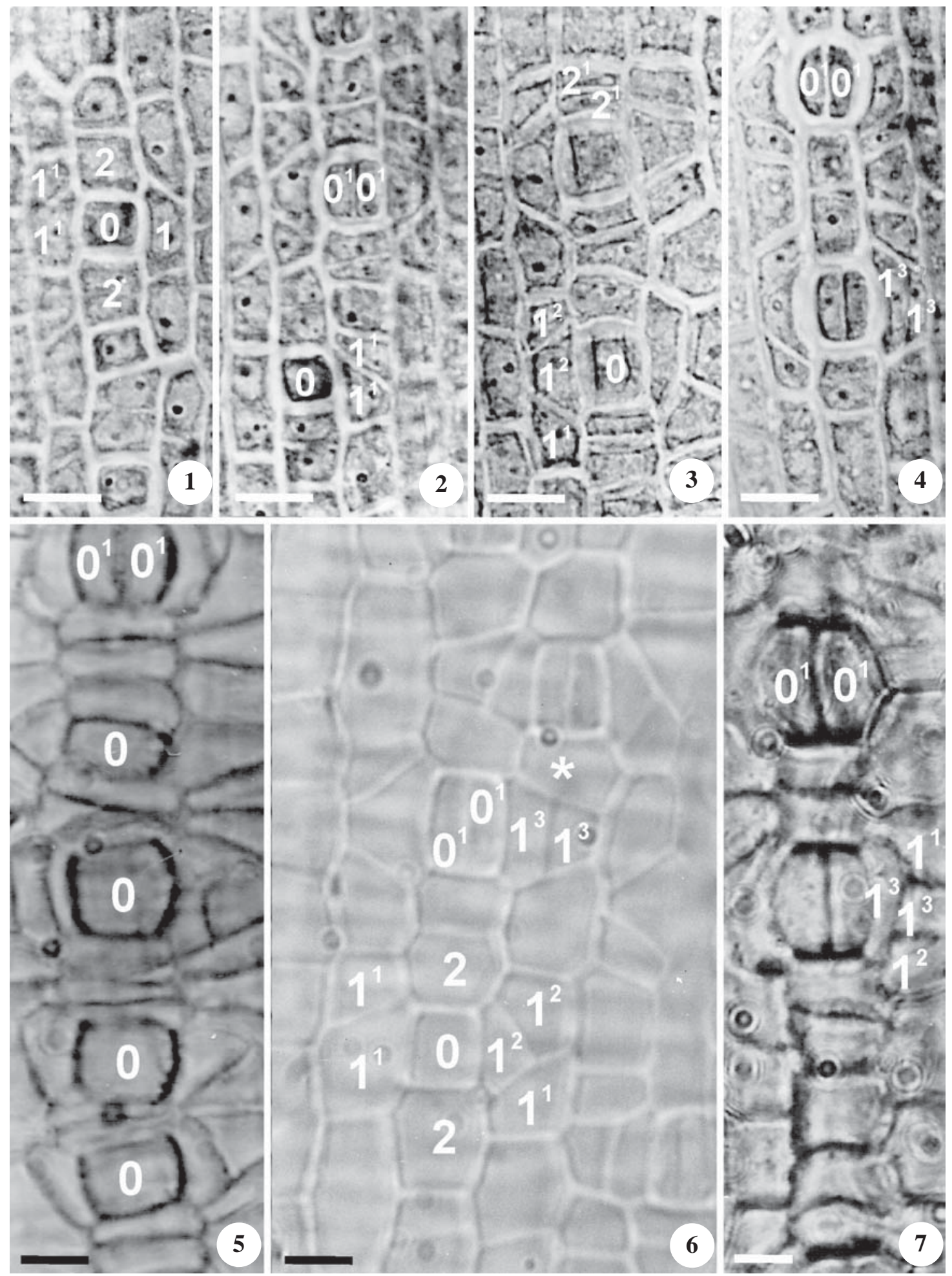

Figures 1-7. Stomatal development. 1-4. Median third of leaf blade of Vellozia epidendroides. 5. Proximal third of leaf blade of Nanuza plicata. 6. Median third of leaf blade of Barbacenia riparia. 7. Proximal third of leaf blade of Vellozia glauca. $\left(0=\right.$ GMC $; 0^{1}=$ guard cell; $1=$ neighbour cell; $1^{1}=$ neighbour cell's daughter; $1^{2}=$ trapezoid cell; $1^{3}=$ trapezoid cell's daughter; $2=$ polar cell, $2^{1}=$ polar cell's daughter; * unclear situations). Bar $=2.5 \mu \mathrm{m}$. 


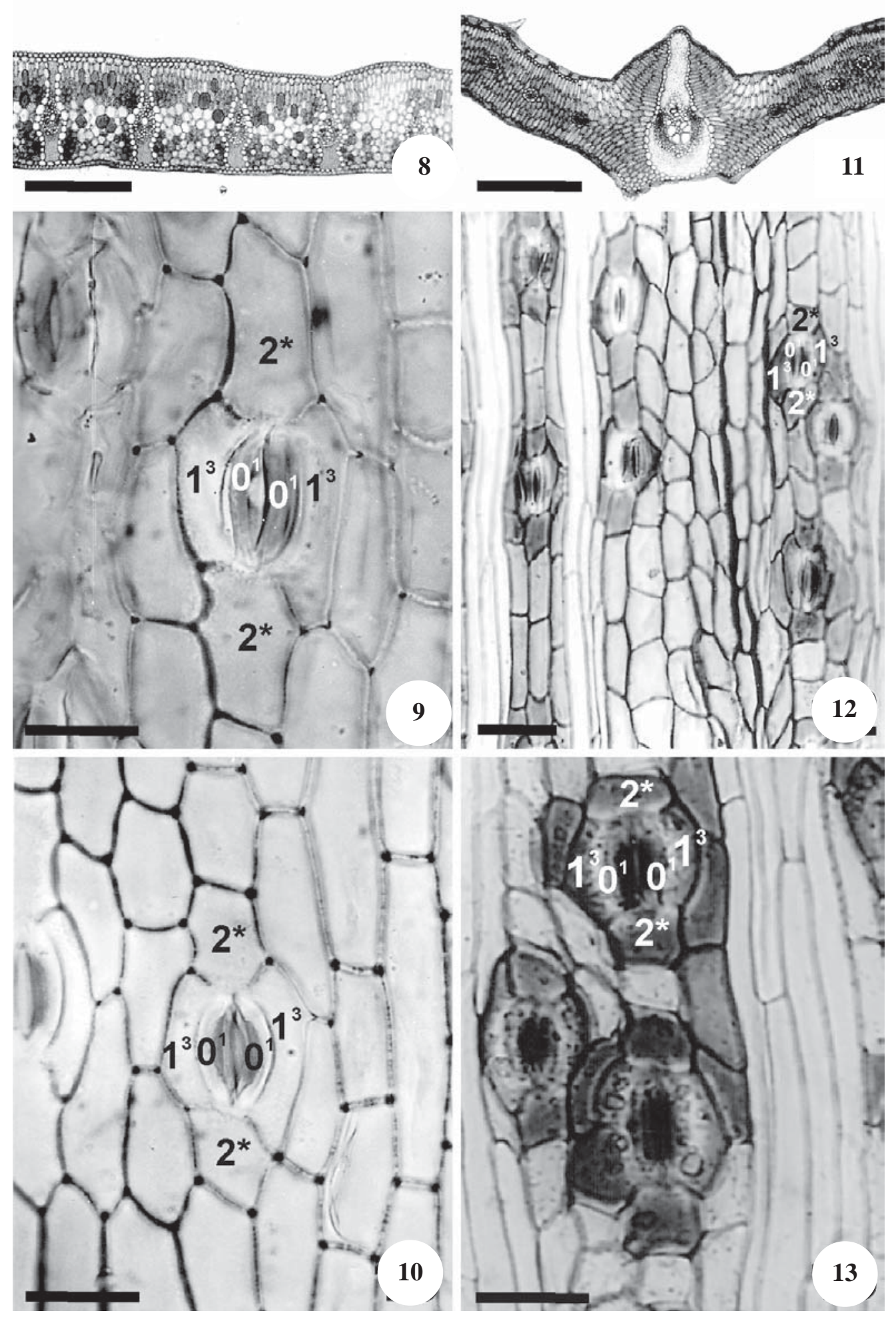

Figures 8-13. Influence of area on stomatal configuration. 8-10. Barbacenia riparia. 11-13. Nanuza plicata. 8 and 11. Transversal section of the median region of leaf blades, furrows absent. 9. Stoma with cells type 2 or $2^{1}\left(2^{*}\right)$ similar to other epidermal cells. 10. Stoma with short cells type 2 or $2^{1}\left(2^{*}\right)$ similar to the closest epidermal cells. 12. Variation in size and shape of cells type 2 or $2^{1}\left(2^{*}\right)$. 13. Stomata surrounded by more than four cells and inserted between rows of needle-like epidermal cells. $\left(0^{1}=\right.$ guard cell; $1^{3}=$ subsidiary cell; $2^{*}=$ polar cell $)$. Bar $=100 \mu \mathrm{m}(8,11), 5 \mu \mathrm{m}(9-10,12-13)$. 

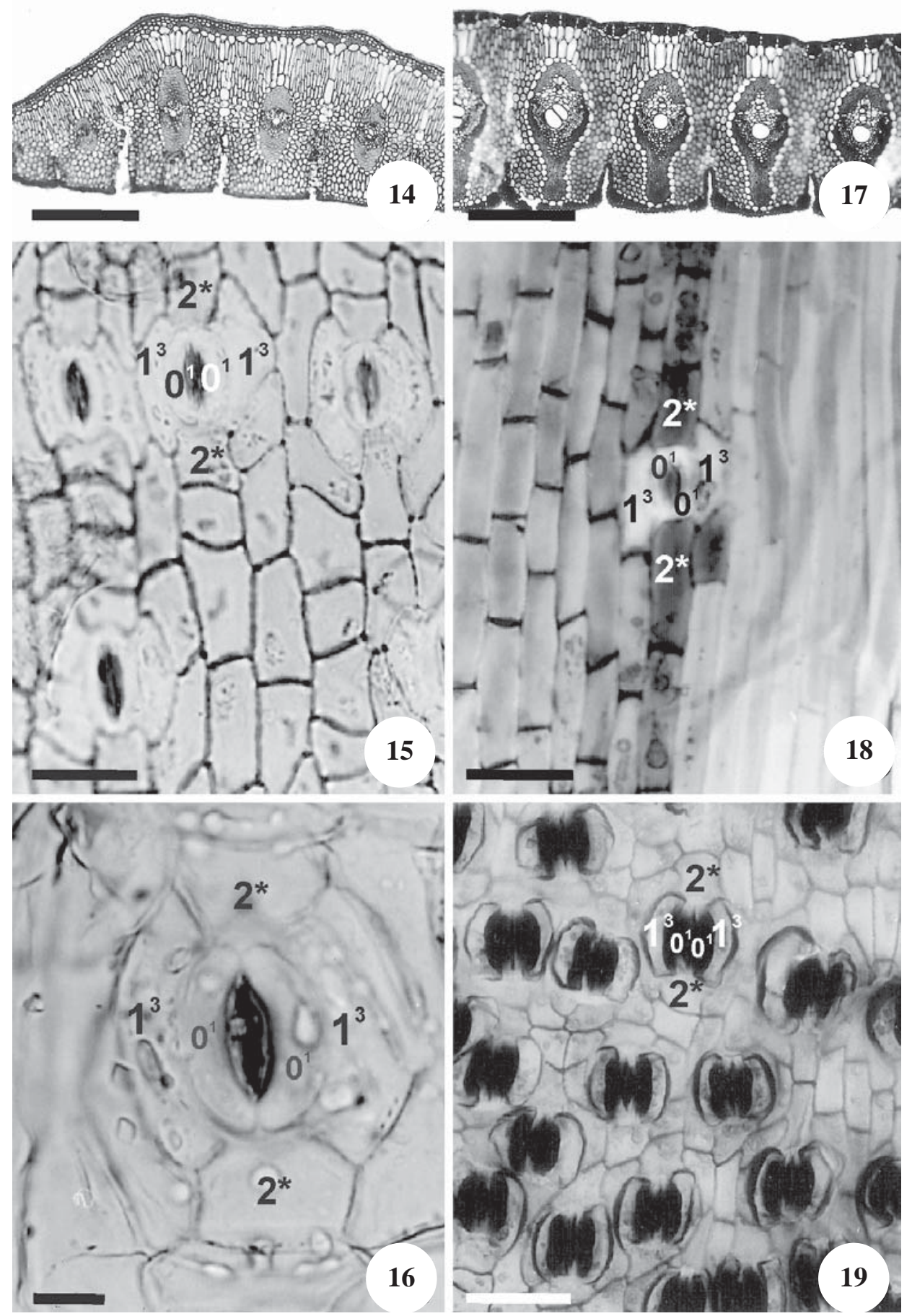

Figures 14-19. Influence of area on stomatal configuration. 14-16. Vellozia epidendroides. 17-19. Vellozia glauca. 14 and 17. Transversal section of leaf blades, showing furrows. 15. Inter-furrows area showing only cells type $1^{3}$, which are distinct from ordinary epidermal cells, and variation in size and shape of cells type 2 or $2^{1}\left(2^{*}\right)$. 16. Furrow area showing short cells type 2 or $2^{1}\left(2^{*}\right)$. 18. Inter-furrows area at centre, showing long cells type 2 or $2^{1}\left(2^{*}\right)$ surrounded by ordinary long epidermal cells, and furrow area, at right, showing short cells type 2 or $2^{1}\left(2^{*}\right)$ surrounded by ordinary short epidermal cells. 19. Furrows area showing short cells type 2 or $2^{1}\left(2^{*}\right)$ surrounded by ordinary short epidermal cells. $\left(0^{1}=\right.$ guard cell; $1^{3}=$ subsidiary cell; $2^{*}=$ polar cell). $\mathrm{Bar}=150 \mu \mathrm{m}(14), 10 \mu \mathrm{m}(15,18$ and 19), $2.5 \mu \mathrm{m}$ (16), $100 \mu \mathrm{m}$ (17). 


\section{Discussion and conclusions}

Data from Barbacenia riparia, Vellozia epidendroides, V. glauca, and V. plicata, indicate that all stomata are periginous. Only two guard cells $\left(0^{1}\right)$ of the stomatal apparatus are products of the GMC (0) (see also Morretes \& Menezes (1969) and Samuel \& Bhat (1994)). The subsidiary cells $\left(1^{3}\right)$ are originated through oblique divisions of the adjacent cells type 1 . This result agrees with Dahlgren \& Rasmussen (1983), who associated the paracytic and tetracytic stomata to the periginous type of Pant (1965). Moreover, these results agree with Tomlinson (1974) and Williams (1979) who observed oblique divisions giving rise to the subsidiary cells in stomata of periginous origin in monocotyledons. The periginous origin is also found among families closely related to the Velloziaceae (e.g. Cyclanthaceae and Pandanaceae) and distantly related families (e.g. Bromeliaceae) (Dahlgren \& Clifford 1982, Dahlgren et al. 1985, Chase et al. 1995, 2000).

Even though the stomata of the four species are of the same origin, they were considered morphologically distinct, bringing up the classification into tetracytic and paracytic stomata (Ayensu 1969, 1974, Menezes et al. 1994, Mello-Silva 2000, 2005). Samuel \& Bhat (1994) found that the number of surrounding cells is equal to the number of faces of the GMCs in Orchidaceae. In Velloziaceae, all the GMCs of the four species studied are surrounded by four cells. We interpreted this characteristic as being due to the rectangular shape of the GMC. Given this pattern, four cells will consequently surround guard cells at maturity. Among those, only the cells type $1^{3}$ are undoubtedly distinct from the other epidermal cells and are found in all regular stomata observed; the cells type 2 and $2^{1}$ reflect the cellular organization pattern of the epidermis, and therefore are not subsidiary.

Tomlinson (1974), Esau (1977), Rasmussen (1981) and Baranova (1987) state that a cell should be considered a subsidiary cell when it is obviously distinct from other epidermal cells. Various studies show that the increase in number of subsidiary cells can be due to their own divisions plus the integration of modified epidermal cells that simulate subsidiary cells (Sen 1958, Pant \& Kidwai 1964, Pant \& Banerji 1965, Pant \& Gupta 1966, Inamdar 1968, Paliwal 1967, Shah 1967, Shah \& Gopal 1969). However, stomatal diversity of the four species of Velloziaceae studied is not a result of the process described in those previous studies. Despite having its two distinct cells type $1^{3}$, tetracytic stoma in Velloziaceae do not present the two obviously distinct cells parallel to the shorter axis of the stoma (cells type 2 or $2^{1}$ ). As a matter of fact, cells type 2 and $2^{1}$ show variations that follow size, shape and arrangement of the common epidermal cells. The misinterpretation that lead to the classification of stomata into paracytic and tetracytic (Ayensu 1974, Menezes et al. 1994, Mello-Silva 2000), was likely due to the incomplete covering of the guard cells by the subsidiary cells. Gaps formed at the top and at the bottom of the stomata are occupied by ordinary cells that have been erroneously considered subsidiary cells. Consequently, a paracytic stoma could be equivocally classified as a tetracytic one. Trying to comprehend stomatal type isolated from the rest of the epidermis has improved these misinterpretations. Aware of that, Dilcher (1974) proposed that only the stomata whose guard cells are completely surrounded by the parallel subsidiary cells should be called paracytic. Those stomata, whose parallel subsidiary cells do not completely surround the guard cells, should be called braquiparacytic.

Thus, the organization of mature stomata reflects the longitudinal space available between the GMCs. In Vellozia epidendroides and in V. glauca a considerable space between the few GMCs in the inter-furrows areas permits the development of the epidermal cells that include cells type 2, leading to stomata classified as "braquiparacytic". On the other hand, the scanty space between the GMCs in the furrows of the lead blades leads to a situation in which the cells type 2 become shorter and inserted between the polar regions of the cells type $1^{3}$ due to the stomatal density. This pattern also leads to braquiparacytic stomata that were once classified as "tetracytic". The entire leaf blade of Barbacenia riparia (which have no furrows) can be compared to the inter-furrows areas described above, also leading to braquiparacytic stomata. There are many regions in which the cells type 2 can be short, following the epidermal cells around. In V. plicata (which also lack furrows) the majority of stomata are found in longitudinal clusters. These clusters could play the same role as the furrows for the development of cells type 2 . This pattern leads to braquiparacytic stomata that were once classified as "tetracytic". In this same species, the insufficient space for the stomatal development could also explain its interruption at the stage of formation of the trapezoid $\left(1^{2}\right)$ cells or even sooner, producing stomata surrounded by more than four cells.

The different patterns of division of the cells type 2 - either oblique or non-oblique - do not lead to different stomatal types. The configuration of the cells type 2 being solely a consequence of the adjustment of the divisions to the space available. In fact, the cells type 2 and $2^{1}$ are 
not subsidiary cells at all and they behave as epidermal cells, which they are. Hence, the stomata of these species of Velloziaceae must be treated as braquiparacytic. Finally, the character "type of stomata" used in cladistic analysis of Velloziaceae (Menezes et al. 1994, MelloSilva 2000, 2005) must be reconsidered and perhaps replaced by a character in which the character states are the number of stomata per area, if these are statistically shown to be discrete.

Acknowledgements - This work results from Marina Amaral's undergraduate project at the University of São Paulo, supported by FAPESP (02/04212-8). The authors also thank Claudia Vecchi and the staff of the Laboratory of Plant Anatomy of the University of São Paulo for help in the lab, Denise Sasaki for field assistance, Edson Rocha de Oliveira for assistance with photographs, and Lúcia G. Lohmann for reviewing the English. Renato de Mello-Silva is a CNPq research fellow.

\section{References}

AYENSU, E.S. 1969. Leaf anatomy and systematics of Old World Velloziaceae. Kew Bulletin 23:315-335.

AYENSU, E.S. 1974. Leaf anatomy and systematics of New World Velloziaceae. Smithsonian Contributions to Botany 15:1-125.

BARANOVA, M.A. 1987. Historical development of the present classification of morphological types of stomata. The Botanical Review 53:53-79.

BUKATSCH, F. 1972. Bemerkungen zur Doppelfarbung Astrablau-safranina. Microkosmos 61:255.

CHASE, M.W., DUVALL, M.R., HILLS, H.G., CONRAN, J.G., COX, A.V., EGUIARTE, L.E., HARTWELL, J., FAY, M.F., CAMERON, K.M. \& HOOT, S. 1995. Molecular phylogenetics of Lilianae. In Monocotyledons: systematics and evolution (P.J. Rudall, P.J. Cribb, D.F. Cutler \& C.J. Humphries, eds.). Royal Botanic Gardens, Kew, p.109-137.

CHASE, M.W., SOLTIS, D.E., SOLTIS, P.S., RUDALL, P.J., FAY, M.F., HAHN, W.H., SULLIVAN, S., JOSEPH, J., MOLVRAY, M., KORES, P.J., GIVNISH, T.J., SYTSMA, K.J. \& PIRES, J.C. 2000. Higher-level systematics of the monocotyledons: an assesment of current knowledge and a new classification. In Monocots: systematics and evolution (K.L. Wilson \& D.A. Morrison, eds.). CSIRO Publishing, Melbourne, p.3-16.

DAHLGREN, R.M.T. \& CLIFFORD, H.T. 1982. The monocotyledons: a comparative study. Academic Press, London.

DAHLGREN, R.M.T. \& RASMUSSEN, F.N. 1983. Monocotyledon evolution. Characters and phylogenetic estimation. Evolutionary Biology 16:255-395.
DAHLGREN, R.M.T., CLIFFORD, H.T. \& YEO, P.F. 1985. The families of the monocotyledons. Springer-Verlag, Berlin.

DILCHER, D.L. 1974. Approaches to the identification of angiosperm leaf remains. The Botanical Review 40: 1-157.

ESAU, K. 1977. Anatomy of seed plants. John Wiley \& Sons, New York.

FRANKLIN, G.L. 1945. Preparation of thin sections of synthetic resins and wood-resin composites, and a new macerating method for wood. Nature 155:3924.

INAMDAR, J.A. 1968. Ontogeny of stomata in some Oleaceae. Proceedings of the Indian Academy of Sciences 67:157164.

JOHANSEN, D.A. 1940. Plant microtechnique. McGrawHill, New York.

KRAUS, J.E. \& ARDUIN, M. 1997. Manual básico de morfologia vegetal. EDUR, Seropédica.

MELLO-SILVA, R. 2000. Partial cladistic analysis of Vellozia and characters for the phylogeny of Velloziaceae. In Monocots: systematics and evolution (K.L. Wilson \& D.A. Morrison, eds.). CSIRO Publishing, Melbourne, p.505-522.

MELLO-SILVA, R. 2005. Morphological analysis, phylogenies and classification in Velloziaceae. Botanical Journal of the Linnean Society 148:157-173.

MENEZES, N.L., MELLO-SILVA, R. \& MAYO, S.J. 1994. A cladistic analysis of the Velloziaceae. Kew Bulletin 49:71-92.

METCALFE, C.R. 1961. The anatomical approach to systematics. General introduction with special reference to recent work on monocotyledons. Recent Advances in Botany 1:146-150.

MORRETES, B.L. \& MENEZES, N.L. 1969. Desenvolvimento de estômatos em folhas e caule de Cobaea scandens. Boletim da Faculdade de Filosofia, Ciências e Letras da Universidade de São Paulo - Botânica 331:49-62.

PALIWAL, G.S. 1967. Ontogeny of stomata in some Cruciferae. Canadian Journal of Botany 45:495-500.

PANT, D.D. 1965. On the ontogeny of stomata and other homologous structures. Plant Science Serie Allahabad $1: 1-24$.

PANT, D.D. \& BANERJI, R. 1965. Epidermal structures and development of stomata in some Convolvulaceae. Senckenbergiana Biologica 46:155-173.

PANT, D.D. \& GUPTA, K.L. 1966. Development of stomata and foliar structure of some Magnoliaceae. Botanical Journal of the Linnean Society 59:265-277.

PANT, D.D. \& KIDWAI, P.F. 1964. On the diversity in the development and organization of stomata in Phyla nodiflora Michx. Current Science 33:653-654.

RAM, H.Y.M. \& NAYYAR, V.L. 1974. A rapid method of obtaining epidermal peels in plants by treatment with cupric sulphate and hydrochloric acid. Stain Technology 40:114-116. 
RASMUSSEN, H. 1981. Terminology and classification of stomata and stomatal development - a critical survey. Botanical Journal of the Linnean Society 83:199212.

SAMUEL, J. \& BHAT, R.B. 1994. Epidermal structure, organographic distribution and ontogeny of stomata in vegetative and floral organs of Stenoglottis fimbriata (Orchidaceae). South African Journal of Botany 60: 113-117.

SEN, S. 1958. Stomata in Centrospermae. Current Science 27:65-67.

SHAH, G.L. 1967. Stomatal development in Convolvulus arvensis Linn. Proceedings of the Indian Academy of Sciences 66:237-242.
SHAH, G.L. \& GOPAL, B.V. 1969. Ontogeny of stomata on the foliar and floral organs of some species of Crotalaria L. Annals of Botany 33:553-560.

STEBBINS, G.L. \& KHUSH, G.S. 1961. Variation in the organization of the stomatal complex in the leaf epidermis of monocotyledons and its bearing on their phylogeny. American Journal of Botany 48:51-59.

TOMLINSON, P.B. 1974. Development of the stomatal complex as a taxonomic character in the monocotyledons. Taxon 23:109-128.

WILLIAMS, N.H. 1979. Subsidiary cells in the Orchidaceae: their general distribution with spatial reference to the development in the Oncidieae. Botanical Journal of the Linnean Society 78:41-66. 